\title{
KONDYCJA INTELEKTUALNA I ETYCZNA BADACZA SPOLECZNEGO
}

Socjologia poczęła się z ducha oświecenia, z rozumu uwznioślonego pragnieniem odmiany świata. Nie zawsze wprawdzie była świadomie zaangażowana politycznie, nie zawsze ulegała pokusie wynajdywania i stosowania socjotechnik, nie zawsze oddawała się marzeniom o „fizyce społecznej” czy „społecznej inżynierii". Co więcej, od stu lat do zasobu socjologicznych klisz należy odżegnywanie się od aspiracji do sterowania procesami społecznymi i udoskonalania świata za pomocą manipulacji opartych na wiedzy z zakresu nauk społecznych. Aspiracje takie uważane są dziś za naiwne, trywialne, a w końcu - nieetyczne. To prawda, taki jest stan ducha przeważającej większości socjologów. Ale właśnie dlatego tak łatwo znika z pola widzenia to zaangażowanie praktyczne, które mimo wszystko w naukach społecznych pozostaje akceptowalne, a nawet pożądane. Gdy socjolog angażuje się w oświecenie publiczne, w budowę wolnego społeczeństwa światłych i tolerancyjnych ludzi, to przecież co najmniej uświadamia współobywatelom trudne i bolesne zjawiska społeczne, z nadzieją, że wesprze społeczeństwo, którego sam jest członkiem, w zwalczaniu przemocy, dyskryminacji, wykluczenia i rozmaitych tzw. patologii społecznych. Nie czuje wtedy żadnych wyrzutów sumienia ani nie odnosi wrażenia, że sprzeniewierza się misji uczonego. Są wszak imponderabilia nowoczesnego człowieka, które bezdyskusyjnie przynależą również do wartości przyświecających uprawianiu socjologii. Kto by odżegnywał się lub choćby ignorował takie wartości społeczne i polityczne, jak równość, sprawiedliwość czy wolność?

Jakiś ślad ideologicznego czy, jak kto woli, moralnego zaangażowania jest w naukach społecznych nie do uniknięcia, jeśli mają uniknąć cynizmu. Niestety

* Prof., Zakład Filozofii i Bioetyki; e-mail: jan.hartman@uj.edu.pl 
obecność wartości w socjologii obarczona jest dwuznacznością, wchodząc w konflikt z elementami etosu beznamiętnego uczonego-obserwatora. Nazywa się ów aksjologiczny naddatek „konstruktywizmem”, ,zaangażowaniem”, „upolitycznieniem”, „subiektywizmem” i na wiele jeszcze sposobów - zawsze z jakąś nutą przygany. Przygana to wszelako jałowa, bo żadnej ucieczki od „zaangażowania” nie ma. Jeśli chciałoby się bowiem, jak to bywało w dobie pozytywizmu i nawet dziś jeszcze się - mocą sentymentu pozytywistycznego - zdarza, za wszelką cenę unikać w naukach społecznych wartościowań, czyli ocen, celem zapewnienia sobie tym większej obiektywności, musi się popaść w śmieszny dogmatyzm i egzaltowaną sztuczność. Unikanie ocen i zaangażowania oznacza bowiem dramatyczne zawężenie rozumienia zjawisk społecznych w stosunku do zupełnie potocznej, nienaukowej ich znajomości. Nie można zakrywać oczu, by mówić obiektywnie o kolorach i nie można uczestniczyć w inteligentnym z natury życiu społecznym - mianowicie w charakterze badacza - tracąc elementarne kompetencje społeczne związane z umiejętnością odróżniania dobra od zła. Tego rodzaju ekscentryczne próby nie tylko same w sobie tchną nieodpowiedzialnością i pyszałkowatością kogoś, kto będąc „ponad to”, chciałby być jedynie „obserwatorem”, lecz w dodatku świadczą o metodologicznej niedojrzałości. Habitus socjologa nie może wszak być uboższy od naturalnych habitusów społecznych, których badaniu chciałby się oddawać. Etos naukowy i etyczny socjologa nie może zaś opierać się na iluzorycznej kreacji idealnego obserwatora bądź innej idealizacji, napędzanej fałszywą świadomością „emancypacji przez kompetencje naukowe”. Wszystko to może co najwyżej irytować bądź gorszyć. Owszem, prawdą jest, że zdania normatywne czy oceniające nie są stwierdzeniami w znaczeniu logiki, nie poddając się operacjom z zakresu klasycznej logiki zdań. Tylko co z tego? Istotne zdania o społeczeństwie, nawet czysto opisowe, zawierają terminy, których w ogóle nie da się pojąć, nie chwytając ich ładunku aksjologicznego, nie mówiąc już o tym, aby mogły mieć jakąkolwiek wartość poznawczą dla kogoś, czy choćby zainteresować kogoś, kto wcale żadnych czynników wartościowych w nich nie dostrzega. Gdy mówimy z zainteresowaniem o jakichś procesach społecznych, to zawsze do pewnego stopnia mamy na uwadze kwestie moralnie doniosłe: Jacy jesteśmy? Co z nami będzie? Tym bardziej, gdy rozważamy konflikty i zmiany społeczne. Albo gdy mówimy o kształtowaniu się instytucji i sposobie ich funkcjonowania. Czemuż to wypierać się tego, że ważne, wręcz najważniejsze w tym wszystkim jest to, czy jest lepiej, czy gorzej, czy będzie lepiej, czy będzie gorzej.

Naiwny obiektywizm, dziecinne pragnienie podglądania świata przez dziurkę od klucza, próżność kogoś, kto pragnie być chłodnym, racjonalnym ekspertem, 
informującym, jak się rzeczy mają - to wszystko są skazy umysłowości oświeceniowej. Paradoksalnie, bo oświecenie to również epoka naiwnej wiary w możliwość daleko posuniętego kontrolowania świata poprzez techniki oparte na wiedzy. Umysłowość ta ma jednakże również piękne strony, jak wiara w człowieka, w postęp (dziś wyklęty, lecz powracający w przebraniu „rozwoju”) i możliwość uprawiania racjonalnej, acz etycznej, nie tak ze szczętem egoistycznej polityki. Nieobce są jej wszelako narowy arogancji, naiwności i próżności, tak charakterystyczne dla wieku młodzieńczego, w którym to przecież nauki społeczne były jeszcze nie tak dawno. Dziś czas by był po temu, aby z młodzieńczości wyróść ostatecznie i wejść w wiek dojrzały. Wielu by tego chciało, lecz zadowalają się łatwym sceptycyzmem lub jakimś bliżej nieokreślonym zawężaniem zadań. Typowy socjolog powie dziś, że socjologia nie może aspirować do rozumienia wszystkiego, co się w społeczeństwie dzieje i nie dostarcza gotowych rozwiązań wszystkich problemów, ale przynajmniej pomaga rozumieć życie społeczne, unikać niektórych błędów, a czasem, być może, podpowiedzieć jakieś rozwiązanie. Poza tym dostarcza informacji empirycznej w rozmaitych kwestiach istotnych z punktu widzenia zarządzania państwem i prowadzenia polityki społecznej. Możemy coś policzyć, sprawdzić, czy coś działa, możemy dowiedzieć się, jaka jest opinia ludzi w jakiejś kwestii, a czy to jest dużo, czy mało, oceńcie sami. Zygmunt Bauman posługuje się tu metaforą wiru na rzece: różne treści życia społecznego przepływają przez wir socjologicznej refleksji - i płyną sobie dalej.

Nie jestem przekonany, czy takie popisy skromności są świadectwem zadowalającego poziomu etycznej i intelektualnej samowiedzy socjologów. Chyba nadal zbyt łatwo przychodzi nam nie brać odpowiedzialności, a to skrywać się za strzępami pozytywistycznego parawaniku „obiektywności” vel „tylko opisowości”, a ostatecznie „refleksyjności”. Trzeba tę rzecz przemyśleć na nowo, bardziej teoretycznie, być może w kierunku, który zarysował Pierre Bourdieu jako autor Zaproszenia do socjologii refleksyjnej czy Zawodu socjologa, odważnie poszukujący transcendentaliów świadomości społecznej i elementarnych praktyk symbolicznych, wspólnych członkom wszystkich klas i grup, socjologów nie wyłączając.

Kieruje nami bowiem pokusa komunikowania się z samymi sobą, a więc w gronie samych badaczy społecznych, takim językiem i na takim poziomie, na jakim komunikujemy się (chwilowo będę się z socjologami, retorycznie, utożsamiał) ze społeczeństwem. Mamy na podorędziu kilka opowieści („narracji”) na użytek, dajmy na to, telewizji, w których tłumaczymy, kim jest „ekspert” i co społeczeństwo może z niego mieć. Ale zapominamy pójść dalej. Skoro wspomnieliśmy Bourdieu - może ,socjologia socjologii” byłaby należytym etycznie 
i intelektualnie postawieniem sprawy krytycznej samowiedzy badacza społecznego? Cóż, „socjologia socjologii” z natury rzeczy musi być czymś w rodzaju demaskatorskiego antymitu środowiskowego. To już coś, ale zbyt łatwo ulec na tym polu pokusie przyjęcia fałszywego alibi, którego dostarcza autoironia. Na szczęście mamy też niesłabnący nurt „socjologii teoretycznej w kryzysie”, gdzie wciąż na nowo rozważa się kwestię: czym właściwie zajmuje się socjo$\log$ ? Wciąż na nowo i z takim samym efektem znudzenia, jaki po przeciwnej stronie - w socjologii empirycznej - wywołuje przytłaczający nadmiar danych. Tak czy inaczej jesteśmy sfrustrowani. Brakuje nam teorii, która tłumaczyłaby, jak to jest, że członek społeczeństwa, jako w takim czy innym sensie racjonalny podmiot praktyk symbolicznych, jako operator znaczeń społecznych, ich współtwórca i użytkownik, jest poniekąd „,małym socjologiem”, a socjolog zawodowy jest jego powiększeniem. Wygląda to na klasyczny mit, oparty na mechanizmie projekcji. Tymczasem ta zadziwiająca relacja jest, o ile mi wiadomo, całkiem nierozpoznana w naukach społecznych, bo też dopiero niedawno społeczeństwo mieszczańskie zaakceptowało socjologiczny punkt widzenia jako wzorzec inteligencji i najbardziej wiarygodny przejaw umysłowej autonomii, dojrzałości i wyemancypowania. Socjologia zainfekowała społeczeństwo liberalne, stając się jakby ortodoksją i teologia jego religii. Owszem, to, w co wierzymy, zawiera jeszcze elementy odpadające z teorii psychologicznych, ekonomicznych i politologicznych, ale to właśnie socjologia nadaje ton. Jakże nisko bądź marginalnie trzeba być dzisiaj usytuowanym w społecznych strukturach, aby nie posługiwać się chociażby słowem „społeczeństwo”, jeszcze kilka dekad temu zupełnie elitarnym. Nauki społeczne muszą zrobić rachunek sumienia i zdać sprawę z tego, w jaki sposób i dlaczego tak radykalnie ingerują w społeczne praktyki dyskursywne i w społeczne formy świadomości. Co więcej - muszą wziąć odpowiedzialność za tę osobliwą metazmianę społeczna, którą wywołały, w przymierzu z mediami i systemem edukacji, coraz bardziej stającym się „wychowaniem do przemądrzałości”.

Zaczyna się to jakoś niewinnie. Można by powiedzieć tak: socjolog w roli eksperta, komunikującego wyniki badań i podającego ich interpretację, pozwalającą zrozumieć coś, co się między nami dzieje, daje społeczeństwu przykład, jak być niezależnie myślącym indywiduum. Z czasem jednak niepostrzeżenie staje się niemal wzorcem człowieka inteligentnego i światłego. Niezliczone wypowiedzi medialne socjologów, stanowiące zasadniczą postać społecznego zakorzenienia środowiska socjologów, uczą społeczeństwo rezonerstwa - bo taki mniej więcej efekt osiaga obywatel próbujący naśladować mentalność i język przedstawiciela nauk społecznych. Socjolog jako rozsadnik socjologicznej inteligencji - oto 
domniemane powołanie współczesnego socjologa. A efekt? „Socjologiczna półinteligenckość" jako najwyższa forma masowego życia umysłowego. Mamy więc w społeczeństwach mieszczańskich naszych czasów coś na kształt słońca kompetencji socjologicznej, które promieniuje kulturą nauk społecznych z ekranów telewizorów i komputerów na niezliczone planety pojedynczych „myślących obywateli", oświecanych i ogrzewanych socjologiczną inteligencją, którą sobie przyswajają i z którą się identyfikują. Narodziło się społeczeństwo rezonerów, komentujących świat, bez specjalnych aspiracji do tego, aby walczyć o swe racje, w przypadku jakichś różnic poglądów, a tym bardziej bez aspiracji, aby świat zmieniać. Jeśli dawniej inteligencja żywo i z przejęciem dyskutowała, z wiarą $\mathrm{w}$ istotność przedmiotu dyskusji, albo choćby obnosiła się z programową (a więc jakoś ideowo zaangażowaną) dekadencją, to dziś raczej praktykuje rytuały odnajdywania się w atmosferze zgody i zrozumienia pomiędzy osobami podobnymi sobie pod względem poziomu umysłowego i kulturalnego. Gdybyż to jeszcze były te słynne konwersacje salonowe. Tam przecież jeszcze liczyła się różnica zdań. Dziś opinia nie musi być oryginalna, broń Boże, nie trzeba też jej bronić. Ważne jest wyłącznie to, aby była opinią i to własną opinią, potwierdzeniem, że nie powtarza się sądów utartych, lecz ma się sąd własny. Jeśli jest akurat bardzo pospolity, to nie szkodzi, byle wypowiedzieć go z odpowiednim naciskiem na własną indywidualność. Spierać się zaś nie ma o co, bo nie prawda się dziś liczy, lecz nastrój umysłu - poczucie niezależności i sceptycznego dystansu. Kto nauczył współczesnego klerka i filistra takiej postawy? Czy nie socjologowie, którzy do mistrzostwa opanowali sztukę perorowania słabych tez, niezobowiązujących interpretacji, a także przemawiania „w imieniu socjologii”, z jak najmniejszą ochotą do tego, aby bronić jakiegoś stanowiska przeciwko innemu, ogłoszonemu także „W imieniu socjologii”? Zapewne działa to również w drugą stronę. Z niedbałego wymądrzania się potocznego czerpie swą energię owo niezobowiązujące, pełne eleganckiej skromności, tweedowe wymądrzanie się akademicko legitymizowanych nauk społecznych. Krytyczny potencjał warstw mieszczańskich wydał socjologię jako swój ostatni, słodki owoc. Owoc, obawiam się, przejrzały.

Anegdoty o społecznym zakorzenieniu środowiska socjologów w kręgach klasy średniej Wschodniego Wybrzeża itp. pozostawmy wszak demaskatorom i plotkarzom. Zejdziemy nieco głębiej, poruszając filozoficzną kwestię relacji między działaniami i zachowaniami „naturalnych” członków społeczeństwa a wypowiedziami socjologów, mającymi ujawniać pewne rationale tych działań i wypowiedzi na jakimś innym poziomie.

Mowa uczonego, w tym również socjologa, musi być akuratna i jednoznaczna. Nie powinna nurzać się w semantycznej grze niedookreślonych i częściowo 
anarchicznych znaczeń. Nie może jej brakować semantycznej przejrzystości i samoopanowania. Nic żywiołowego - wszystko pod logiczną i refleksyjną kontrolą. Ideał tyleż ekscentryczny, co anachroniczny. Wszak wymyślono go w XVII wieku, celem pozbycia się religijnego rządu dusz, rzekomo działającego poprzez przewrotne niejednoznaczności i sprytne sztuczki z naszymi uczuciami i wyobraźnią. „Powiedzieć wszystko” - w dodatku ,jasno i wyraźnie”. Po co? Aby nie pozostawić już miejsca dla żadnego demona, który chciałby zakraść się do naszych dusz i odebrać nam część naszej autonomii. Wypełnić się szczelnie i bez reszty pewnością, oczywistością i jasnością - oto sposób na zachowanie siebie. Sposób doskonały, tyle że w efekcie zabójczy. Oczywistości bowiem i ja sam oprzeć się nie mogę, rozpływam się w niej i znikam, nie gorzej niż w fanatycznej, zabobonnej wierze.

Czy możemy więc odrzucić naiwną sugestię, że socjologia odkrywa ,prawdziwe znaczenia" wypowiedzi naiwnych, pozornie znaczących coś innego, niż znaczą naprawdę, czyli coś innego niż rola, jaką pełnią w budowaniu i podtrzymywaniu jakiegoś bytu społecznego? Sugestia to naiwna, bo stawiająca socjologa w roli egzegety „prawdy o społeczeństwie”, a nawet demaskatora „ukrytych mechanizmów”, ale, niestety, bardzo trudna do oddalenia. Niezwykle trudno wyeliminować z wyobraźni socjologicznej paternalistyczne kategorie związane z ,aktorami społecznymi” odgrywającymi pewne „role”, w ramach pewnych „rytuałów” lub ,praktyk”. Pewnego sposobu poradzenia sobie z uwierającym nas poczuciem arogancji i naiwności dostarcza nurt etnometodologii, razem z pokrewną mu socjologią wiedzy, a w naszych czasach dyskusje wokół kontrowersji obiektywizm-subiektywizm w teorii społecznej. Zakłada się tu, że istnieje jakaś ciągłość między praktykami komunikacyjnymi (w tym również wiedzotwórczymi), którym oddaje się na co dzień społeczeństwo, a analogicznymi praktykami samych socjologów. Dyskurs socjologii jest więc przetworzeniem i przekształceniem dyskursów, jakie towarzyszą praktykom społecznym, a w tym również takich, które służą członkom społeczeństwa do wyrażania własnej świadomości społecznej. Na czym to przetworzenie polega? Na systematyczności, na utrzymywaniu wyższej dyscypliny logicznej, na trwałej samokontroli, na użyciu pewnych danych i wiedzy specjalistycznej, a także na pewnej pracy i wkładzie etycznym - na uwalnianiu się od uprzedzeń i dogmatów, na pełniejszej emancypacji umysłowej i kulturalnej. W tej wizji socjolog jest awangardą społeczeństwa, kimś par excellence oświeconym, ale nie przeciwstawnym społeczeństwu, jako mentor lub krytyk, lecz zaprzyjaźnionym ze społeczeństwem - jako najsprawniejszy wyraziciel jego samowiedzy i jego aspiracji. Czyż Habermas nie pełni roli mędrca, który daje społeczeństwu głos samowiedzy i podnosi jego godność do 
rangi atrybutu organizacji intelektualnie i etycznie samoświadomej i wyemancypowanej? Oświecenie ostatecznie spełnione, chciałoby się rzec. Niestety, system ten nie działa, gdyż zamiast zmieniać społeczeństwo w przestrzeń niekończącej się debaty, organizuje je w strukturę bezkolizyjnych partykularyzmów, zarządzanych przez quasi-ideologię etycznie i racjonalnie nieodpartych zasad pokojowego współistnienia i pokojowej debaty. Efekt jest mierny, gdyż debaty zaczynają się i kończą na „metarytuałach”, czyli składaniu sobie wzajemnie deklaracji wierności zasadom tolerancji, pluralizmu i poszanowania równych praw; konflikty społeczne rozstrzyga się zaś, po dawnemu, w konfrontacji sił i negocjacjach interesów.

Postkantowska utopia, której oddaje się znaczna część środowisk nauk społecznych, całkiem już się znudziła i zbankrutowała. Wraz z nią upadł jednak cały ów model, przekształcający socjologa-mentora czy inżyniera społecznego w socjologa-moderatora, spolegliwego akuszera racjonalnych zmian na lepsze. Habermas nie jest przewodnikiem mas ani prorokiem, ale nie jest też ,profesorem mas", jak chcieliśmy go postrzegać jeszcze ćwierć wieku temu. A to dlatego, że masy po prostu nie korzystają z usług profesorów, a profesorowie świadczą swe usługi nie masom, lecz elitom. Głos ludu i głos elit nie mogą się pojednać. Już tyle razy się o tym przekonaliśmy, że jeszcze ten jeden raz - mianowicie w przypadku J. Habermasa - nie zaszkodzi już ani nie pomoże. Albo to rozumiemy, albo nie. Socjolog nie jest ani antytezą masy w dialektycznym procesie zdobywania przez nią samoświadomości, nie jest jej „towarzyszem podróży”, pilotem wycieczki przez dzieje społeczeństwa, nie jest wieszczem, ni bardem, nie jest też profesorem społeczeństwa. Kim jest?

Być może socjolog jest analitykiem zbiorowej nieświadomości, to znaczy kimś, kto opowiada równoległe historie, na motywach znanych i zrozumiałych dla odbiorców krańcowych socjologicznej narracji, czyli dla w miarę inteligentnych członków społeczeństwa. Robi to, co psycholog, mówiący nam ,jacy jesteśmy”, utrwalający naszą miłość własną, a jednocześnie pomagający uwolnić się od demonów lęku, frustracji i innych nieprzyjemności egzystencjalnych. Również dyskurs socjologa musi być budujący, łagodzący, balsamiczny. Socjolog także „przemawia” do społeczeństwa z terapeutyczną wyrozumiałością. Wprawdzie istnieje socjologia ezoteryczna, coś, co jest przeznaczone tylko dla uszu innych socjologów, ale przecież dokłada się starań, aby wzmocnić więź socjologów ze społeczeństwem, zwiększyć transparencję i przystępność arkanów socjologii dla laików, a zwłaszcza dla studentów, którzy jako reprezentanci laików przychodzą na studia socjologiczne. Wszystko to jednak skończyło się źle. Socjologiczne czułe pasterzowanie przyczyniło się do wyjałowienia umysłowego szerokich rzecz klasy średniej, małpujących socjologiczną nowomowę, a w efekcie pro- 
dukujących kapłańską kastę socjologów w głębi duszy tak samo dotkniętą wada skromnej i niekonkluzywnej refleksyjności, co przeciętny wyznawca i konsument socjologicznej publicystyki.

Nauki społeczne, jak widzimy, znalazły się w modernistycznym klinczu. Uwięzły w splocie ambicji i idiosynkrazji o społecznym $\mathrm{i}$ intelektualnym podłożu, które dziś jest już anachroniczne, razem z całą spuścizną nowoczesności. Czeka nas zasadnicza przebudowa - na poziomie etosu, metodologii i społecznego umocowania nauk społecznych. Doszliśmy do ściany - doczekaliśmy się społeczeństwa wyemancypowanego, złożonego z mniej czy bardziej karykaturalnych socjologicznych homunkulusów - małych socjologów. Nawet bowiem prosty i naiwny uczestnik społecznych praktyk musi być przez nas postrzegany jako mały socjolog in spe - jest wszak kimś, komu należy się edukacja i emancypacja. Gdy zaś te staną się jego udziałem, zamieni się niechybnie w inteligenta, czyli epigona socjologów. Socjologia widzi w swoim przedmiocie samą siebie, przegląda się w zwierciadle społeczeństwa, które coraz bardziej łączy się z polem nauk społecznych w jedno pole, zdefiniowane przez habitus uteoretycznionej świadomości społecznej. Wypiera ona świadomość religijną i społeczną mitologię w zdumiewającym tempie. Wydaje się, jakby jedyną przeszkodą dla transformacji współczesnych społeczeństw w „społeczeństwa socjologów” było naturalne lenistwo i nieuctwo większości zdrowych ludzi. Ale i oni coś tam mówią - a gdy już mówią, to brzmi to właśnie jak parodia wyemancypowanej, acz miernej, letniej i poprawnej mowy inteligenta.

Nie potrafię wskazać wyjścia z tej heurystycznej i moralnej pułapki. Z pewnością jednak nauki społeczne w XXI wieku muszą wziąć na siebie odpowiedzialność za uwolnienie społeczeństw od nawisu jałowej refleksyjności, którą na swoją modłę narzuciły mu, wraz z anachroniczną i moralnie dwuznaczną koncepcją intelektualnej emancypacji jako zachowania racjonalnego dystansu do „zjawisk społecznych”. Początkiem tego procesu sanacji stosunków pomiędzy naukami społecznymi a społeczeństwem musi być, rzecz jasna, diagnoza zaistniałej patologii. Przyczynkiem do niej jest między innymi niniejszy skromny esej. Co dalej? Jeśli miałbym zgadywać, w którym kierunku potoczy się reforma nauk społecznych, to postawiłbym na zerwanie z kategoriami humanistycznymi, które zdają się być najbardziej czytelne dla ogółu i dobrze już zaabsorbowane przez dyskursy społeczne. Socjologia może oderwać się od społeczeństwa, którym chcąc nie chcąc manipuluje, stając się dla niego mniej zrozumiała i mniej interesująca. Oznacza to, iż musi mniej mówić o „człowieku” i „,społeczeństwie”. Istnieją już takie obszary teorii społecznej, w których w centrum uwagi nie stoi już figura „człowieka”. Posthumanistyczny charakter ma na przykład filozofia 
społeczna G. Deleuze `a i F. Guattariego. Nie widać jednak, aby nauki społeczne z szacunkiem i zrozumieniem podchodziły do trudnych, a tym samym nieco ekscentrycznych, koncepcji filozoficznych. Mam nadzieję, że w przyszłości to się zmieni. Socjologia ma bowiem akurat tyle samowiedzy, ile potrzebuje dla własnej legitymacji. Gdy ta legitymacja została podważona, można było przez jakiś czas udawać, że to nieprawda. Obecnie jednak samolegitymizujące nauki społeczne sprzężenie socjologicznej wiedzy z samowiedza, rozumianą jako standardowa metasocjologia, już nie działa. Kryzys jest ewidentny. Niezbędna jest operacja na drugim piętrze refleksji - metametasocjologia. To jest już wszelako zadanie filozoficzne. Wstępem do niej był powyższy tekst. 